\title{
Impact of loneliness in the elderly in health care: a cross-sectional study in an urban region of Portugal
}

\author{
CATARINA ROCHA-VIEIRA ${ }^{1, A-F}$, GUSTAVO OLIVEIRA ${ }^{2, A, ~ C-F}$, LUCIANA COUTO 1, 3, 4, A, D, E \\ ORCID ID: 0000-0002-8147-3197 \\ ORCID ID: 0000-0003-1165-4707 \\ ORCID ID: 0000-0001-6567-993X \\ PAULO SANTOS $3,4, A, C-G$ \\ ORCID ID: 0000-0002-2362-5527 \\ ${ }^{1}$ USF Camelias, ACES Gaia, Vila Nova de Gaia, Portugal \\ ${ }^{2}$ USF Garcia d'Orta, ACES Porto Ocidental, Portugal \\ ${ }^{3}$ MEDCIDS - Department of Medicine of Community, Information and Health Decision Sciences, \\ Faculty of Medicine of Porto, Portugal \\ ${ }^{4}$ CINTESIS - Center for Health Technology and Services Research, University of Porto, Portugal
}

A - Study Design, B - Data Collection, C - Statistical Analysis, D - Data Interpretation, E - Manuscript Preparation, F - Literature Search, $\mathbf{G}$ - Funds Collection

Summary Background. Loneliness is a subjective, complex and multi-dimensional feeling, having a significant impact on mental health. It is related to intrinsic and extrinsic factors.

Objectives. The aim of this study is to evaluate the impact of loneliness in elderly patients in medical care.

Material and methods. We conducted a cross-sectional study of a sample of 150 participants, aged $\geq 65$ years, interviewed by a structured questionnaire, including the University of California Los Angeles Loneliness Scale (UCLA-LS), for assessment of loneliness. Other variables included socio-demographic characterisation and family dysfunction. Total medication prescription and polymedication were used to assess the medical care assistance profile. Logistic regression was used for multivariate analysis.

Results. The prevalence of moderate to severe loneliness was $36 \%(95 \% \mathrm{Cl}: 28.3-44.2 \%)$, higher with ageing, without differences between gender. The greatest impact in loneliness occurred in the presence of family dysfunction, income dissatisfaction, living alone and ageing. Being married/in a non-marital partnership and maintaining professional activity appeared as protective factors. The perception of loneliness was related with polymedication, with higher levels of loneliness matching with higher polymedication.

Conclusions. Loneliness is common in the geriatric population and interferes significantly with health care; thus, it can be considered a determinant of health. Incorporating this factor into clinical decision reasoning is crucial for better health care.

Key words: geriatrics, loneliness, social isolation, polypharmacy, poverty, family conflict.

Rocha-Vieira C, Oliveira G, Couto L, Santos P. Impact of loneliness in the elderly in health care: a cross-sectional study in an urban region of Portugal. Fam Med Prim Care Rev 2019; 21(2): 138-143, doi: https://doi.org/10.5114/fmpcr.2019.84550.

\section{Background}

Most of people, if not all, experience feelings of loneliness sometime in their life, without constituting a significant problem or representing a pathological process $[1,2]$. Perhaps because of this, loneliness is still a neglected issue when compared to other social problems [3], despite the growing interest in recent years.

Loneliness is the result of the discrepancy between desired social relations and those effectively built [4]. It is a subjective, multi-dimensional and complex feeling, with a strong impact on mental health, particularly in the elderly. Loneliness can be determined by intrinsic factors, such as personality or the loss of autonomy, as well as by extrinsic factors, such as poor social networks and deficits in affective standards $[3,4]$.

Although it is associated with isolation, loneliness is conceptually different, because it derives from the unpleasant perception of the lack of a social support network $[5,6]$. On the other hand, isolation corresponds to the perception of a real physical separation, which can be passive or active. Concurrently, loneliness may exist without isolation and isolation without loneliness $[5,6]$.

Although loneliness may exist throughout ones' lifetime, the elderly are particularly vulnerable due to their fragility and proximity to loss. It represents a strong threat to their health and quality of life [7]. Several studies associate loneliness with sleep disturbances, depressive symptoms, somatisation, hemodynamic instability, falls and accidents, as well as to a lower compliance to medical therapy [8-10].

This is particularly relevant if we consider the huge ageing of the population, with the number of elderly increasing both in absolute and relative terms due to better living conditions, the promotion of healthier lifestyles and advances in the prevention of disease. Population-ageing is a reality in western countries, and the strategies classically outlined to dealing with this do not work anymore, especially within the family structure and the disappearance of extended families $[11,12]$.

The concept of ageing has changed over the time by the influence of greater and more profound knowledge of human anatomy [13].

In a physiological degeneration perspective, ageing is the progressive, persistent and age-dependent decline of the intrinsic physiological functions of the individual, leading to a reduction of the reproducibility rate and an increase of mortality [14, 15]. In the population perspective, ageing is defined as the age-related loss of adaptation, caused by the progressive decline of the forces of natural selection $[14,15]$. 
Ageing is not a pathological process, but rather an accumulation of progressive changes within the biological, psychological and social dimensions, evolving over a lifetime from an early age, even before birth $[16,17]$. Although inevitable, human ageing is very irregular, with a huge interindividual variation [18]. This heterogeneity results from the interaction between several intrinsic determinants, such as unique genetic information, and extrinsic factors, from environment and lifestyle [16, 17]. Losses and specific needs affect quality of life and lead to the reorganisation of daily routines, many times a real challenge in each case, [18] implying the reformulation of each individual's priorities.

Finding answers for ageing-related problems impose new medical, social, cultural, political and financial demands, aiming to monitor its evolution and to minimise the negative impacts in people. The perspective of ageing as an active process opens opportunities for health $[12,19,20]$, increasing participation and security and promoting success in adaptation to changing, increasing the perception of well-being and the quality of life [21].

However, loneliness may compromise this success, leading to a downward spiral, which is hard to stop.

\section{Objectives}

The aim of this study is to evaluate the impact of loneliness in people of 65 years of age or older in medical care, searching for the relationship with socio-demographic factors, comorbidities and family functioning. A better characterisation of loneliness in the elderly will contribute to the implementation of prevention strategies for better ageing.

\section{Material and methods}

We conducted a cross-sectional study at the Family Health Centre (USF) Camélias, in the north of Portugal, from July to September 2017.

\section{Participants}

Participants were consecutively recruited among patients 65 years of age or older and who went to the primary care setting for a medical or nurse appointment and had agrred to participate.

The sample size of 150 subjects was calculated based on an expected prevalence of loneliness in the elderly of about 30\% [22] and a maximum error of $7.5 \%$ for a $95 \%$ confidence interval [23].

Participants were asked to fill in a questionnaire, with the aid of the interviewer, if deemed necessary. It included three dimensions: socio-demographic characterisation (age, gender, marital status, household size, education, employment status and income satisfaction), family functionality and the perception of loneliness. Electronic clinical files were checked for chronic medication.

Two groups were fixed according to age (65-79 years of age and 80 or more years of age). Household size was categorised by those who live alone, those who live with a partner and those who had descendants, even those not living with them in the same house. Instead of the financial quantification, we asked for the satisfaction with total income, representing the subjective point of view of participants (Dissatisfied, Average and High).

Family functionality was assessed by the Family APGAR Questionnaire [24]. This test uses five questions about a patient's perception of family adaptability, partnership, growth, affection and resolve. Each of its five questions is ranked from 0 to 10 points, and the final score, translated by the sum of the partial scores, classifies families as being "severely dysfunctional" (0 to 3 points), "moderately functional" (4 to 6 points) and "highly functional" (7 to 10 points) [24, 25].

The University of California in Los Angeles Loneliness Scale (UCLA-LS) [26] evaluated the degree of loneliness experienced by patients. We used the Portuguese validated version $[27,28]$, containing eighteen questions, each scoring from 1 to 4 points. The total sum ranges from 18 to 72 points. It always infers some degree of loneliness from 19 points up. This scale allows for categorisation at three levels of increasing perception of loneliness, from "low level of loneliness" (19-36 points), "moderate level of loneliness" (37-54 points), to "severe level of loneliness" (55-72 points) [29, 30].

The number of chronic prescribed medications was assessed from the electronic clinical file. Polymedication was defined by the chronic consumption of 5 or more drugs a day [31-33].

\section{Ethical aspects}

Data was anonymised for analysis. All participants signed the informed consent form, previously to the inclusion. Procedures were consistent with the Helsinki Declaration and the Oviedo Convention for the protection of human rights and dignity of the human being regarding the application of biology and medicine. The study protocol fell under the supervision and acceptance of the Ethical Committee of Portuguese North Health Administration (process number 96/2017).

\section{Statistical procedures}

Data was registered into a digital database using Microsoft ${ }^{\mathrm{TM}}$ Excel $^{\circledR} 2016$ and treated by SPSS ${ }^{\circledR}$ version 22.

We used descriptive and dispersion measures to analyse the sample characteristics, calculating the frequency for the categorical and nominal variables, as well as the average, median and standard deviation for the continuous variables.

The sample was compared with the population of the health centre using the Spearman correlation and the chi-square test for age and gender distribution. The prevalence of loneliness on the entire population was estimated by direct adjustment for age and gender. We used the modified Wald method for the calculation of confidence intervals at a $95 \%$ level.

Data analysis was performed based on gender (males and females) and age (categorised into two groups, 65 to 79 years of age and 80 years of age or more).

For inferential analysis, we used the chi-square test to evaluate the association between categorical variables and the $t$-student in continuous variables, after checking for normal distribution by the Kolmogorov-Smirnov test or nonparametric tests. The outcome variable loneliness was dichotomised in no/low loneliness (UCLA-LS score lower than 36 points) and moderate/ /severe loneliness (ICLS-LS score equal or higher than 36 points). Logistic regression was used in univariate analysis to calculate the estimate of the odds ratio and in multivariate analysis after adjustment for the variables with statistical significance by the backward stepwise method. We accepted an alpha error of 0.05 .

\section{Results}

We included 150 elderly patients (61.3\% females), with ages ranging between 65 and 94 years of age (mean age $=74.7 \pm 7.5$ years) and $68.7 \%$ below 80 years of age $(n=103)$. Table 1 shows the demographic characteristics of the sample. The sample was not significantly different to the population of the city of Vila Nova de Gaia, where the health centre was located and where $16 \%(n=47274)$ of its inhabitants are over 65 years of age [76\% below 80 years of age $(n=35941)$ and $24 \%$ over 80 years of age $(n=11333)]$, of which $43 \%(n=20233)$ were males and $57 \%$ ( $n=27$ 041) were females.

The age groups presented significant differences in marital status and employment, as expected, but also in education and income satisfaction. Our population also showed significant differences between gender in education and in employment status, with males presenting a higher level of education and greater job permanence. 


\begin{tabular}{|c|c|c|c|c|c|c|}
\hline \multirow{3}{*}{$\begin{array}{l}\text { Gender, } n(\%) \\
\text { Male } \\
\text { Female } \\
\end{array}$} & \multicolumn{4}{|c|}{ Age } & \multirow{2}{*}{\multicolumn{2}{|c|}{$\begin{array}{l}\text { Total } \\
n=150(100 \%)\end{array}$}} \\
\hline & \multicolumn{2}{|c|}{$\begin{array}{l}<80 \text { years } \\
n=103(68.7 \%)\end{array}$} & \multicolumn{2}{|c|}{$\begin{array}{l}\geq 80 \text { years } \\
n=47(32.3 \%)\end{array}$} & & \\
\hline & $\begin{array}{l}45 \\
58\end{array}$ & $\begin{array}{l}(43.7) \\
(56.3)\end{array}$ & $\begin{array}{l}13 \\
34\end{array}$ & $\begin{array}{l}(27.7) \\
(72.3)\end{array}$ & $\begin{array}{l}58 \\
92\end{array}$ & $\begin{array}{l}(38.7) \\
(61.3)\end{array}$ \\
\hline $\begin{array}{l}\text { Marital status, } n(\%) \\
\text { Single } \\
\text { Married/non-marital partnership } \\
\text { Divorced } \\
\text { Widowed }\end{array}$ & $\begin{array}{l}6 \\
84 \\
9 \\
4\end{array}$ & $\begin{array}{l}(5.8) \\
(81.6) \\
(8.7) \\
(3.9)\end{array}$ & $\begin{array}{l}2 \\
9 \\
3 \\
33\end{array}$ & $\begin{array}{l}(4.3) \\
(19.1) \\
(6.4) \\
(70.2)\end{array}$ & $\begin{array}{l}8 \\
93 \\
12 \\
37\end{array}$ & $\begin{array}{l}(5.3) \\
(62.0) \\
(8.0) \\
(24.7)\end{array}$ \\
\hline $\begin{array}{l}\text { Family size, } n(\%) \\
\text { Lives with a partner } \\
\text { No descendants } \\
\text { Lives alone }\end{array}$ & $\begin{array}{l}67 \\
10 \\
13 \\
\end{array}$ & $\begin{array}{l}(65.0) \\
(9.7) \\
(12.6)\end{array}$ & $\begin{array}{l}8 \\
4 \\
20\end{array}$ & $\begin{array}{l}(17.0) \\
(8.5) \\
(42.6) \\
\end{array}$ & $\begin{array}{l}75 \\
14 \\
33 \\
\end{array}$ & $\begin{array}{l}(50.0) \\
(9.3) \\
(22.0)\end{array}$ \\
\hline $\begin{array}{l}\text { Education, } n(\%) \\
<4 \text { years } \\
\text { Primary education } \\
\leq 9 \text { years } \\
\leq 12 \text { years } \\
\text { College or higher }\end{array}$ & $\begin{array}{l}2 \\
49 \\
20 \\
24 \\
8\end{array}$ & $\begin{array}{l}(1.9) \\
(47.6) \\
(19.4) \\
(23.3) \\
(7.8)\end{array}$ & $\begin{array}{l}14 \\
27 \\
1 \\
4 \\
1\end{array}$ & $\begin{array}{l}(29.8) \\
(57.4) \\
(2.1) \\
(8.5) \\
(2.1) \\
\end{array}$ & $\begin{array}{l}16 \\
76 \\
21 \\
28 \\
9\end{array}$ & $\begin{array}{l}(10.7) \\
(50.7) \\
(14.0) \\
(18.7) \\
(6.0)\end{array}$ \\
\hline $\begin{array}{l}\text { Employment status, } n(\%) \\
\text { Active } \\
\text { Unemployed } \\
\text { Retired } \\
\text { Domestic } \\
\end{array}$ & $\begin{array}{l}41 \\
1 \\
57 \\
4\end{array}$ & $\begin{array}{l}(39.8) \\
(1.0) \\
(55.3) \\
(3.9)\end{array}$ & $\begin{array}{l}0 \\
1 \\
41 \\
5\end{array}$ & $\begin{array}{l}(0.0) \\
(2.1) \\
(87.2) \\
(10.6) \\
\end{array}$ & \begin{tabular}{|l}
41 \\
2 \\
98 \\
9
\end{tabular} & $\begin{array}{l}(27.3) \\
(1.3) \\
(65.3) \\
(6.0)\end{array}$ \\
\hline $\begin{array}{l}\text { Income satisfaction, } n(\%) \\
\text { Dissatisfied } \\
\text { Average } \\
\text { High }\end{array}$ & $\begin{array}{l}23 \\
76 \\
4\end{array}$ & $\begin{array}{l}(22.3) \\
(73.8) \\
(3.9)\end{array}$ & $\begin{array}{l}38 \\
8 \\
1\end{array}$ & $\begin{array}{l}(80.9) \\
(17.0) \\
(2.1)\end{array}$ & $\begin{array}{l}61 \\
84 \\
5\end{array}$ & $\begin{array}{l}(40.7) \\
(56.0) \\
(3.3)\end{array}$ \\
\hline $\begin{array}{l}\text { Family dysfunction (APGAR), } n(\%) \\
\text { Severe dysfunction } \\
\text { Moderate dysfunction } \\
\text { Functional }\end{array}$ & $\begin{array}{l}12 \\
8 \\
83\end{array}$ & $\begin{array}{l}(11.7) \\
(7.8) \\
(80.6)\end{array}$ & $\begin{array}{l}24 \\
11 \\
12\end{array}$ & $\begin{array}{l}(51.1) \\
(23.4) \\
(25.5)\end{array}$ & $\begin{array}{l}36 \\
19 \\
95\end{array}$ & $\begin{array}{l}(24.0) \\
(12.7) \\
(63.3)\end{array}$ \\
\hline
\end{tabular}

* Chi-square test; NS - non-significant.

The presence of family dysfunction, measured by the Family APGAR score, also varied significantly between the age groups, both in the total score and in the individual analysis of each of its dimensions (adaptability, partnership, growth, affection and resolve). The group $\geq 80$ years of age showed greater severe dysfunction and less family functionality, without differences between gender.

Fifty-four of the elderly presented an UCLA-LS score higher than 36 , representing a perception of moderate to severe loneliness. The prevalence of loneliness in this sample was 36\% (95\% Cl: $28.3-44.2 \%)$. In the cut-off of 19 points on the UCLA-LS, i.e. any degree of loneliness perception, the prevalence of loneliness raised to $91.3 \%$ (95\% Cl: 85.6-95.3\%).

A severe level of loneliness was present in $30.7 \%(95 \% \mathrm{Cl}$ : 23.4-38.7\%), 5.3\% (95\% Cl: 2.3-10.2\%) expressed a moderate level of loneliness, and 55.3\% (95\% Cl: 47.0-63.5\%) experienced a low level of loneliness. The remaining thirteen participants $(8.7 \%$ of the sample: $95 \% \mathrm{Cl}: 4.7-14.4 \%$ ), did not show any level of loneliness. The estimative of prevalence of loneliness for the population of the entire health centre is $36.7 \%$ ( $95 \% \mathrm{Cl}$ : $35.1-38.3 \%)$.

The degree of loneliness varied with age (greater in the $\geq 80$ years of age group) and income satisfaction (greater in more unsatisfied). We noticed a higher tendency in females, though not statistically significant.

Table 2 shows the impact of socio-demographic variables in loneliness perception in univariate analysis. The variables were dichotomised by clinical criteria, using loneliness perception (cut-off $>36$ ) as the outcome.

An age of $\geq 80$ years, living alone, education $<9$ years, dissatisfaction with income and family dysfunction were associated with a greater perception of loneliness. On the other hand, being mar- ried or in a non-marital partnership and maintaining professional activity appeared to condition lower perception of loneliness.

\begin{tabular}{|c|c|c|c|}
\hline & OR & Cl 95\% & $p^{*}$ \\
\hline Age $\geq 80$ years & 12.895 & $5.661-29.374$ & $<0.001$ \\
\hline Male & 0.616 & $0.305-1.244$ & 0.175 \\
\hline $\begin{array}{l}\text { Married/non-marital } \\
\text { partnership }\end{array}$ & 0.063 & $0.028-0.144$ & $<0.001$ \\
\hline Living with a partner & 0.174 & $0.082-0.369$ & $<0.001$ \\
\hline Having descendants & 0.528 & $0.175-1.595$ & 0.258 \\
\hline Living alone & 19.600 & $6.882-55.822$ & $<0.001$ \\
\hline Education $<9$ years & 2.489 & $1.045-5.929$ & 0.040 \\
\hline $\begin{array}{l}\text { Maintaining profes- } \\
\text { sional activity }\end{array}$ & 0.052 & $0.012-0.224$ & $<0.001$ \\
\hline $\begin{array}{l}\text { Dissatisfaction with } \\
\text { income }\end{array}$ & 96.591 & $29.195-319.572$ & $<0.001$ \\
\hline $\begin{array}{l}\text { Presence of family } \\
\text { dysfunction (APGAR) }\end{array}$ & 2491.000 & $220.630-28124.316$ & $<0.001$ \\
\hline
\end{tabular}

* Univariate logistic regression; OR - odds ratio; $\mathrm{Cl}$ - confidence interval; NS - non-significant.

These findings were strengthened in the multivariate analysis. The presence of severe family dysfunction $(O R=338.18$; $p<0.001)$ and dissatisfaction with income $(\mathrm{OR}=17.52 ; p<0.001)$ were significantly associated with the perception of loneliness by the elderly. 


\begin{tabular}{|c|c|c|c|c|c|c|c|c|}
\hline & & \multicolumn{4}{|c|}{ Age } & \multirow{2}{*}{\multicolumn{2}{|c|}{$\begin{array}{l}\text { Total } \\
n=150\end{array}$}} & \multirow[t]{2}{*}{$p^{*}$} \\
\hline & & \multicolumn{2}{|c|}{$\begin{array}{l}<80 \text { years } \\
n=103\end{array}$} & \multicolumn{2}{|c|}{$\begin{array}{l}\geq 80 \text { years } \\
n=47\end{array}$} & & & \\
\hline \multicolumn{8}{|c|}{ I feel like I'm a part of a group of friends, $n(\%)$} & \multirow[t]{5}{*}{$<0.001$} \\
\hline \multirow[t]{4}{*}{ "Inverse" question } & never (4 points) & 15 & $(14.6)$ & 30 & $(63.8)$ & 45 & (30.0) & \\
\hline & rarely (3 points) & 18 & $(17.5)$ & 11 & $(23.4)$ & 29 & $(19.3)$ & \\
\hline & sometimes ( 2 points) & 37 & $(35.9)$ & 6 & $(12.8)$ & 43 & $(28.7)$ & \\
\hline & frequently (1 points) & 33 & $(32.0)$ & 0 & $(0.0)$ & 33 & $(22.0)$ & \\
\hline \multicolumn{8}{|c|}{ I don't feel intimate with anyone, $n$ (\%) } & \multirow[t]{5}{*}{$<0.001$} \\
\hline & never (1 points) & 40 & $(38.8)$ & 0 & $(0.0)$ & 40 & $(26.7)$ & \\
\hline & rarely ( 2 points) & 23 & $(22.3)$ & 1 & $(2.1)$ & 24 & $(16.0)$ & \\
\hline & sometimes ( 3 points) & 16 & $(15.5)$ & 8 & $(17.0)$ & 24 & $(16.0)$ & \\
\hline & frequently (4 points) & 24 & $(23.3)$ & 38 & $(80.9)$ & 62 & (41.3) & \\
\hline \multicolumn{8}{|c|}{ There are people I can turn to, $n(\%)$} & \multirow[t]{5}{*}{$<0.001$} \\
\hline \multirow[t]{4}{*}{ "Inverse" question } & never (4 points) & 5 & (4.9) & 2 & (4.3) & 7 & $(4.7)$ & \\
\hline & rarely (3 points) & 8 & $(7.8)$ & 17 & $(36.2)$ & 25 & $(16.7)$ & \\
\hline & sometimes ( 2 points) & 5 & (4.9) & 15 & (31.9) & 20 & $(13.3)$ & \\
\hline & frequently ( 1 points) & 85 & $(82.5)$ & 13 & (27.7) & 98 & (65.3) & \\
\hline
\end{tabular}

* Chi-square test.

Analysing the different components of UCLA-LS, we can verify that the questions mostly counting towards loneliness perception were "I feel like I'm a part of a group of friends" and "I don't feel intimate with anyone", which scored negatively, thus increasing the perception of loneliness. The question "There are people I can turn to" scored positively, seeming to be protective. The group above 80 years of age showed worse results in both items (Table 3).

Loneliness interferes with medical care, as seen through chronic drug prescriptions. We accepted the definition of polymedication as the chronic consumption of 5 or more drugs per day. Polymedication was present in 62 patients $(41.3 \%, 95 \% \mathrm{Cl}$ : $33.4-49.7 \%)$, more in the group above 80 years of age, with no differences between gender. Our data showed an increase of the risk of polymedication in the elderly presenting loneliness (OR = 46.9; 95\% Cl: 16.9-130.0; $p<0.001)$. We also noticed a positive correlation between loneliness and number of daily chronic drugs (Spearman $=0.706 ; p<0.001$ ) (Figure 1 ).

\section{Discussion}

Nine out of ten elderly individuals report some level of loneliness, and more than $1 / 3$ experience loneliness in moderate to severe intensity. This is particularly evident in people older than 80 years of age, irrespective of gender, where a higher perception of loneliness is also accompanied by family dysfunction.

Our results are slightly higher than other studies, where loneliness in the elderly varies between $14 \%$ and $25 \%$ [7, 9, 34]. Moreover, $22 \%$ of our population lives alone, which is close to the USA reality of $26 \%$, but significantly below the European mean of $32 \%$, climbing to $45 \%$ above 80 years of age [5].

Although the experience of loneliness is subjective and singular, there are several significant determinants to the impact on individual perception. Our study shows that the presence of family dysfunction, according to the Family APGAR, and dissatisfaction with income are major factors in the perception of loneliness in the elderly. However, an age $\geq 80$ years old, living

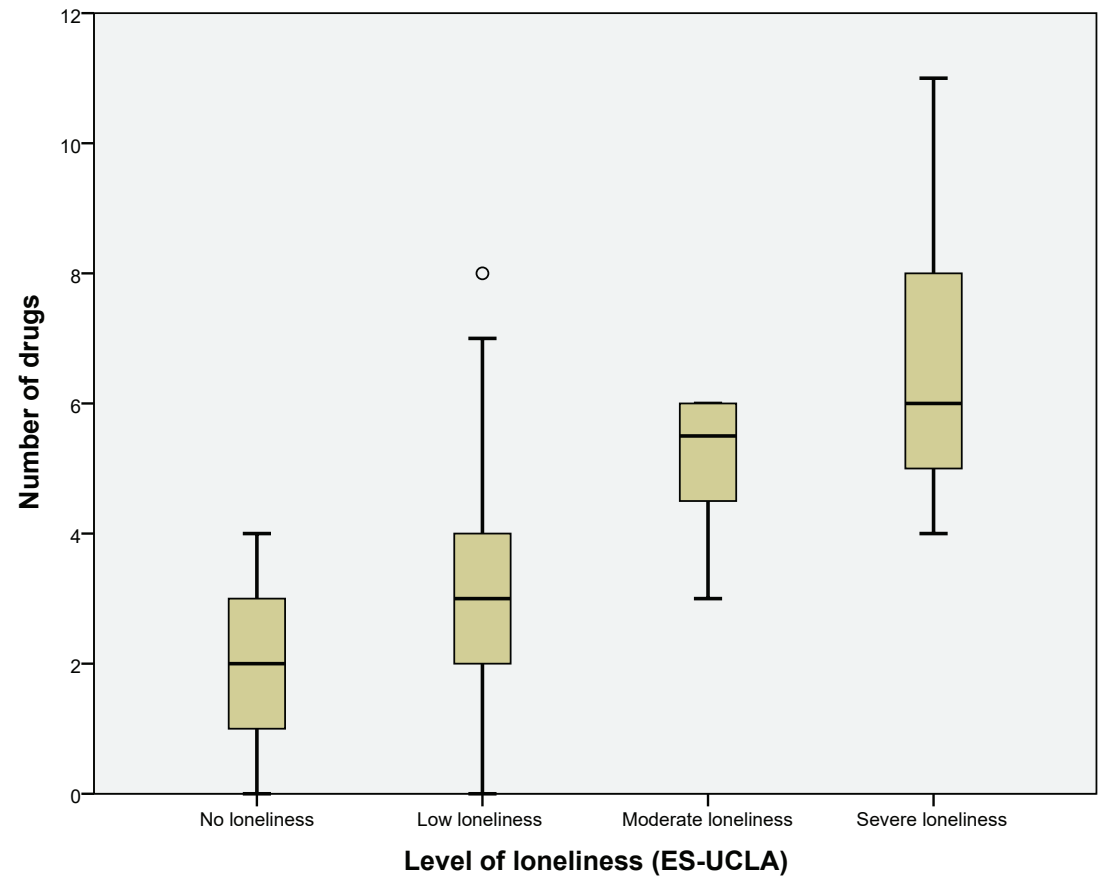

Figure 1. Relationship between the level of loneliness and the number of drugs 
alone and education $<9$ years are also important contributors. On the other hand, having company and maintaining an active professional life are protective factors.

When we evaluate the different dimensions of the UCLA-LS the lack of friends and the lack of intimate relationships were the main contributors to the perception of loneliness. Conversely, having someone to turn to in the face of adversity was the factor with the greatest influence on reducing loneliness.

Moreover, loneliness leads to an increase in the demand for medical care, as proven by the relation with the great consumption of chronic medications, especially in the group over 80 years of age. It is crucial to understand this interaction between a social network and health care and to integrate it in health decision-making. We perceive that patients living alone without a supportive social network appeal to the health system, somaticising their suffering and putting them at risk of overmedicalisation. In modern societies, being old is many times also the subject of discrimination and stigma, conditioning individuals' living choices, healthy ageing and their quality of life.

We must change mentalities, joining efforts in fighting loneliness in the elderly. Active ageing is defined by the World Health Organization since 2002 as "the process of developing and maintaining the functional ability that enables wellbeing as ageing occurs" [35]. Our results confirm that work activity is a protective factor of loneliness. Therefore, political, legislative, social and health measures should stimulate the elderly to maintaining a variety of appropriate daily activities even after retirement, thus promoting the preservation of social utility and protecting against loneliness.

Loneliness requires a global approach to deal with the multifactorial process. Age and its associated losses are important factors in the increased perception of loneliness, but living alone, dissatisfaction with income and the presence of family dysfunction appear as major associated elements. In this sense, good social and family supportive networks are useful to prevent loneliness despite ageing. As we have stated, more loneliness also means more medical care needs and more chronic medication taken. Strategies for investment to control loneliness will improve health outcomes and reduce the potential harms of overdiagnosis and polymedication.
In any case, loneliness is an important issue in the elderly, and efforts should be made to prevent its occurrence and, if not possible, to fight it when present. Simple acts such as providing company, promoting a healthy and participative family life, maintaining daily activities to ensure social utility and improving social contact using day-care centres are examples of strategies that may reduce loneliness, thus improving health outcomes.

Guidelines for the health of the elderly should incorporate social dimensions, such as companionship, adequate income and social utility, as preventive approaches to health. However, these values are often forgotten in policies, in social frameworks and even within families [36].

The city of Vila Nova de Gaia, where this study took place, presents a resident population over 65 years old of $15.4 \%$, slightly lower than the national statistics of $19.3 \%$, according to official numbers of Census 2011. About $38.7 \%$ of elders live alone versus $46.9 \%$ throughout the entire country. These differences may condition the possibility to extrapolate data nationwide, but they stress the importance of the conclusions of this study: If more than $1 / 3$ of the elderly show a moderate to severe perception of loneliness, in this urban area, with less elderly, and particularly less isolated elderly, then, in other regions with worst scenarios, loneliness can be even more evident. Nevertheless, this is an important limitation that we took into consideration.

On the other hand, although we used a single scale for the assessment of loneliness, the UCLA-LS is one of the most valid and robust tools to measure it since it was first published in 1978 [26]. Moreover, it has also been used in several Portuguese studies [28] with good reliability.

\section{Conclusions}

This study characterises the impact of loneliness in a Portuguese urban region. Loneliness is a common situation among the elderly and impacts medical care, being associated with an increased number of daily chronic medications.

Thus, loneliness interferes with health balance. To take good care of our elders, we must look for the social framework and "prescribe" better family relationships and adequate pensions, aiming to improve the health outcomes and to prevent a possible overmedicalisation of ageing.

Source of funding: This work was funded from the authors' own resources.

Conflicts of interest: The authors declare no conflicts of interest.

\section{References}

1. Peplau LA, PerIman D. Loneliness: a sourcebook of current theory, research, and therapy. New York: Wiley; 1982: xvii, 430.

2. Monteiro H, Félix N. Universidades da terceira idade: da solidão aos motivos para a sua frequência. Porto: LivPsic; 2008 (in Portuguese).

3. Neto F. Psicologia social. Vol. II. Lisboa: Universidade Aberta; 2000.

4. Heinrich LM, Gullone E. The clinical significance of loneliness: a literature review. Clin Psychol Rev 2006; 26(6): 695-718, doi: 10.1016/j. cpr.2006.04.002.

5. Gomes A, Maspoli A. Solidão: uma abordagem interdisciplinar pela ótica da teologia bíblica reformada. Fides Reformata 2001; VI(1) [cited 10.11.2018]. Available from URL: http:// www.mackenzie.br/teologia/fides/vol06/num01/Maspoli.pdf (in Portuguese).

6. Fernandes P. A Depressão no idoso. Coimbra: Quarteto Editora; 2000 (in Portuguese).

7. Singh A, Misra N. Loneliness, depression and sociability in old age. Ind Psychiatry J 2009; 18(1): 51-55, doi: 10.4103/0972-6748.57861.

8. Cacioppo JT, Hawkley LC, Thisted RA. Perceived social isolation makes me sad: 5 -year cross-lagged analyses of loneliness and depressive symptomatology in the Chicago Health, Aging, and Social Relations Study. Psychol Aging 2010; 25(2): 453-463, doi: $10.1037 / a 0017216$.

9. Cacioppo JT, Hughes ME, Waite LJ, et al. Loneliness as a specific risk factor for depressive symptoms: cross-sectional and longitudinal analyses. Psychol Aging 2006; 21(1): 140-151, doi: 10.1037/0882-7974.21.1.140.

10. Kamińska MS, Brodowski J, Karakiewicz B. The influence of socio-demographic and environmental factors on the fall rate in geriatric patients in primary health care. Fam Med Prim Care Rev 2017; 19(2): 139-143, doi: 10.5114/fmpcr.2017.67869.

11. Santos P. Prevention of accidents involving elderly. Patient Care (ed port) 2010; 15(157): 65-70 (in Portuguese).

12. Paplicki M, Susło R, Dopierała K, et al. Systemic aspects of securing the health safety of the elderly. Fam Med Prim Care Rev 2018; 20(3): 267-270, doi: 10.5114/fmpcr.2018.78272.

13. Paúl MC, Fonseca AM. Envelhecer em Portugal. Lisboa: Climepsi Editores; 2006 (in Portuguese).

14. Flatt T. A new definition of aging? Front Genet 2012; 3: 148, doi: 10.3389/fgene.2012.00148.

15. Fabian D, Flatt T. The evolution of aging. Nature Edu Know 2011; 3(10): 9.

16. Direção Geral da Saúde. Programa Nacional para a Saúde das Pessoas Idosas. Lisboa: Direção Geral da Saúde; $2006: 24$ (in Portuguese).

17. Figueiredo D. Cuidados familiares ao idoso dependente. Lisboa: Climepsi Editores; 2007 (in Portuguese).

18. Fontaine R. Psicologia do Envelhecimento. Lisboa: Climepsi Editores; 2000 (in Portuguese). 
19. Monteiro H, Neto F. A Solidão em pessoas idosas: universidades da terceira idade. Psic Edu Cult 2006; 1: 183-286 (in Portuguese).

20. Gonçalves C, Carrilho MJ. Ageing - an increasing phenomenon with geographical diferences. Rev Est Demog 2007; 40(2): 21-37 (in Portuguese).

21. Sousa L, Galante H, Figueiredo D. Quality of life and well-being of elderly people: an exploratory study in the Portuguese population. Rev Saúde Publ 2003; 37(3): 364-371 (in Portuguese).

22. Neto F. Socio-demographic predictors of loneliness across the adult life span in Portugal. Interpersona 2014; 8(2): 222, doi: 10.5964/ ijpr.v8i2.171.

23. Hulley SB. Designing clinical research. 3rd ed. Philadelphia (PA): Lippincott Williams \& Wilkins; 2007: xv, 367.

24. Smilkstein G. The family APGAR: a proposal for a family function test and its use by physicians. J Fam Pract 1978; 6(6): $1231-1239$.

25. Smilkstein G, Ashworth C, Montano D. Validity and reliability of the family APGAR as a test of family function. J Fam Pract 1982; 15(2): 303-311.

26. Russell D, Peplau LA, Ferguson ML. Developing a measure of loneliness. J Pers Assess 1978; 42(3): 290-294, doi: 10.1207/s15327752jpa4203_11.

27. Neto F. Avaliação da solidão. Psic Clin 1989; 2: 65-79 (in Portuguese).

28. Pocinho M, Farate C, Dias CA. Validação psicométrica da escala UCLA-Loneliness para idosos portugueses. Interações 2010; 10(18): 65-77 (in Portuguese).

29. Costa MD, Espirito-Santo H. Sentimentos de solidão, correlatos e preditores. Coimbra: ISMT Repositório; 2012 (in Portuguese).

30. Valada MJS. A arte da vida: caminhar pelo envelhecimento com resiliência e com qualidade de vida. Lisboa: ULHT-Faculdade de Psicologia; 2011 (in Portuguese).

31. Bjerrum L, Sogaard J, Hallas J, et al. Polypharmacy: correlations with sex, age and drug regimen. A prescription database study. Eur J Clin Pharmacol 1998; 54(3): 197-202.

32. Veehof L, Stewart R, Haaijer-Ruskamp F, et al. The development of polypharmacy. A longitudinal study. Fam Pract 2000; 17(3): $261-267$.

33. Silva P, Luís S, Biscaia A. Polymedication: a prevalence study at the Lumiar and Queluz Health Centres. Rev Port Med Geral Fam 2004; 20(3): 323-336 (in Portuguese).

34. Victor CR, Yang K. The prevalence of loneliness among adults: a case study of the United Kingdom. J Psychol 2012; 146(1-2): 85-104, doi: 10.1080/00223980.2011.613875.

35. United Nations. Report of the Second World Assembly on Ageing. Madrid: United Nations; 2002 8-12 April 2002. Contract No.: A/CONF.197/9.

36. Santos P, Nazare I, Martins C, et al. The Portuguese Guidelines and patients values. Acta Med Port 2015; 28(6): $754-759$ (in Portuguese).

Tables: 3

Figures: 1

References: 36

Received: 8.10.2018

Reviewed: 1.11.2018

Accepted: 17.12.2018

Address for correspondence:

Paulo Santos, MD, PhD, Assoc. Prof.

Department of Medicine of Community,

Information and Health Decision Sciences Faculty of Medicine

University of Porto

Alameda Hernani Monteiro, $\mathrm{S} / \mathrm{N}$

4200-319 Porto

Portugal

Tel.: 00351936004916

E-mail: psantosdr@med.up.pt 